深海性二枚貝における埋在と付着の意義

\title{
Significance for Deep-sea Bivalves of Life-styles Buried in the Sediment or Attached to Objects
}

\author{
大越健嗣 ${ }^{1) *} \cdot$ 大越和加 ${ }^{2)} \cdot$ 藤倉克則 ${ }^{3)}$ \\ 1) 石巻専修大学理工学部. $\bar{\top} 986-8580$ 石巻市南境新水戸1 \\ 2) 東北大学大学院農学研究科. $=981-8555$ 仙台市青葉区堤通雨宮町 1-1 \\ 3) 海洋科学技術センター海洋生態・環境研究部。广237-0061 横須賀市夏島町 2-15
}

\section{$\mathrm{Kenji} \mathrm{OKOSHI}^{1)}{ }^{*}$, Waka SATO-OKOSHI ${ }^{2)}$ and Katsunori FUJIKURA ${ }^{3)}$}

\author{
${ }^{1)}$ Department of Biotechnology, Ishinomaki Senshu University, I Shinmito, Minamisakai, Ishinomaki, \\ Miyagi 986-8580, Japan \\ 2) Laboratory of Aquatic Ecology, Division of Environmental Bioremediation, Graduate School of Agricultural Science, \\ Tohoku University, 1-1 Tsutsumidori, Amamiyamachi, Aoba-ku, Sendai 981-8555, Japan \\ 3) Japan Marine Science and Technology Center, 2-15 Natsushima-cho, Yokosuka, Kanagawa 237-0061, Japan
}

\begin{abstract}
Bivalves belonging to the families Vesicomyidae and Mytilidae, which thrive in deep-sea hydrothermal vents and cold seeps, live in symbiosis with chemoautotrophic bacteria. The present paper discusses the significance of differences in the life-styles of deep-sea bivalves and shallow-water ones, considering both those buried in the sediment and those attached to objects. The life-styles of bivalves that live buried in the sediment in shallow water are shaped by adaptations related to feeding on plankton and detritus, orientation, burrowing, and so on. Mussels living in shallow water use byssus to attach themselves to solid objects for feeding and orientation. The byssus also serves to protect them from strong wave action, preventing them from being swept off the rock surface. Deep-sea clams of the genus Calyptogena absorb hydrogen sulfide from the bottom at deep-sea hydrothermal vents and cold seeps. They do not feed on particulate matter. Deep-sea mussels of the genus Bathymodiolus attach themselves to chimneys and rocks, and to living and dead shells of the same species. Because of high hydrothermal vent activity, some of the chimneys grow 40 to $50 \mathrm{~cm}$ taller within a day. The surface structure of the chimneys and the temperature of their environment vary from day to day. In the case of the wave-free hydrothermal vent environment, tight attachment by byssus provides no advantage. The functional and/or ecological significance of the attachment is most likely different between shallowwater mussels and deep-sea ones.
\end{abstract}

Key Words: byssus, deep-sea clam, deep-sea mussel, hydrothermal vent, life-style.

\section{深海化学合成生物群集に生息する二枚貝}

深海の熱水噴出域や泠水湧出域にはさまざまな分類群に 属する生物が発見されている. 現在でも次々に新種が記載 され, 無春椎動物全体では 1991 年に 236 種 (Tunnicliffe 1991, 1992)であったものが 1998 年には 443 種 (Tunnicliffe et al. 1998) がリストアップされている. 軟体動物の二枚貝 類はそれら化学合成生物群集の主要な構成種となっている が，これまではシロウリガイ Calyptogena soyoae に代表さ れるオトヒメハマグリ科 Vesicomyidae の貝類とイガイ科 Mytilidae のシンカイヒバリガイ属 Bathymodiolus の報告が

Received 27 Feb. 2003 Accepted 8 May 2003

*: Corresponding author
多く, 少数のッキガイ科 Lucinidae, ハナシガイ科 Thyasiridae, キヌタレガイ科 Solemyidae の貝類を除けば，これ ら 2 科に属する二枚貝類が化学合成生物群集の主要な構成 種であるということができる (奥谷 2000a)，オトヒメハマ グリ科の貝類ではアケビガイ Calyptogena kawamurai でも 生息水深は $100 \mathrm{~m}$ 以深上考えられており, 浅海に近縁なむ のはほとんど生息していない，一方，イガイ科に属するシ ンカイヒバリガイ属は浅海に多くの近縁種が生息してい る.こ枕でシロウリガイ属は約 20 種, シンカイヒバリガ イ属は約 15 種が新種として記載されているが, 近年もキ ザミオトヒメハマグリVesicomya crenulomarginata やヤイ バシロウリガイ Calyptogena (Archivesica) magnocultellus (Okutani et al. 2002) のように次々と新種が報告されてお り, 今後記載が進めば両者で 50 種を超えるのではないか と考えられる. シロウリガイ属は鰓に硫黄細菌が共生して 
おり泥中から硫化水素を, シンカイヒバリガイ属は硫黄細 菌またはメ夕ン酸化細菌, 種によってはその両方が共生し ており海水中のメタンや海水由来の硫黄などを取り入れて 化学合成を行っている (Nelson and Fisher 1995; Yamanaka et al. 2000; 藤原 2003; 溝田・山中 2003).

\section{二枚貝の生活様式}

二枚貝は進化の過程でさまざまな生活様式を獲得してき た. それらは大きく分けると岩盤や海底表面に付着や固着 している表生生活者と砂泥底に埋没したり木材・岩石など に穿孔して生活している内生生活者に分けることができる (Seilacher 1985; 近藤 2001). 浅海に生息する二枚貝類では シロウリガイ属のように砂や泥中に埋在するタイプ（アサ リRuditapes philippinarum やハマグリ Meretrix lusoria な ど), シンカイヒバリガイ属のように足糸で基盤に付着す るタイプ（ムラサキイガイ Mytilus galloprovincialis やムラ サキインコガイ Septifer virgatusなど）の他にマガキCrassostrea gigas やゥミギク Spondylus barbatusなどのように貝 款で直接基盤に固着する夕イプ，さらに岩盤や木材に穴を 掘る穿孔者といわれるタイプに大きく分けることができ る. 埋在する種はすぐる深さやすぐる能力の達いによって さらに細かく分けられている（近藤 2001）。的ように 貝壳で固着するタイプの生活様式をもつ二枚貝は浅海では 繁栄しているものが多いが, 深海の熱水噴出域や冷水溥出 域の化学合成生物群集のリスト (Tunnicliffe et al. 1998) の 中にはこのタイプの二枚貝が欠けていることが特徴として 挙げられる，また，穿れ者も知られていない，熱水噴出域 や泠水涌出域以外の深海の貝類相については, これまでの ところ, 足系付着型の二枚貝では水深 $3,000 \mathrm{~m}$ のビームト ロールでワダッミフネガイ Bentharca asperula が採集され ており（土田 2000）、マメヒバリガイ Modiolus margaritaceus やサガミワタゾコエガイ Bathyarca sagamiensis も水 深数百 $\mathrm{m}$ まで分布していることが知られている（奥谷 2000b). 一方, 表在固着型といわれる二枚貝はベッコゥガ キ Neopycnodonte cochlear やギンパクイシガキ Dimya japonica，オオナデシコ Spondylus anacanthus などが水深数 $100 \mathrm{~m}$ まで分布することが知られているが $1,000 \mathrm{~m}$ 以深に 生息する種の報告は見あたらない，足系付着と貝殸による 固着の中間型を示すナミマガシワ科 Anomiidae でもシマ ナミマガシワモドキ Monia umbonata の $300 \mathrm{~m}$ が最深であ る. 以上のことから, 足系付着型二枚貝はバイオマスとし ては小さいが，熱水噴出域や泠水湧出域以外の深海底にも 少数生息しており，一方，表在固着型二枚貝は，これまで のところ熱水噴出域や冷水湧出域には生息か確認されてお らず，それ以外の数百 $\mathrm{m}$ までの海底に少数生息している のみであることがわかる.

\section{固签性二枚貝の進化}

ところで，固着性二枚貝は捕食者の増大に対処するもの として進化してきたという説 (Harper 1991) が提出されて いる.これはヨーロッパイガイ Mytilus edulis を足系で基 盤に付着させたものと樹脂で基盤に固着させたものを用意 し，ヒトデやカ二がどちらを選択し捕食するかという実験 を行い，足系付着の方が有意に捕食されたという結果か ら，固着様式の進化を捕食者の行動との関連で論じたもの である. 沖縄トラフの黒島海丘は水深 $600 \sim 650 \mathrm{~m}$ の冷水 涌出域が広がり，そこには複数の未記載種のシンカイヒバ リガイが生息している（藤倉ら 2003）。生息水深としては 固着性二枚貝のギンパクイシガキの最深の生息水深とほぼ 同じレベルであるが固着性二枚貝は発見されていない，二 枚貝の捕食者となりうる数種のヒトデやカニは生息してい る (藤倉ら 2003). したがって, 深海の化学合成生態系の構 成要員として固着性二枚貝が欠けていることを Harper (1991) の言うように捕食者との関連だけで説明すること は困難であると考えられる.

深海域では二枚貝類は波や干出にさらされることがな い，浅海域では師となるはずの植物プランクトンる深海に はいない，細菌と共生することにより摄眲活動そのあのの 活性がないかまたは低い，深海は暗黒で低温の環境が連続 し，年変動や季節変化もほとんどなく，ある意味では安定 した環境である、一方, 高圧といった特殊な条件す付加さ れる. したがって, 深海の化学合成生物群集の一員になる には, 浅海から深海底へのルート,さらにバクテリアとの 共生関係の成立, 浅海とは異なる物理化学的な環境の中で の成長と再生産の成功というさまざまなハードルがある. イガイ科二枚只の深海への進出は, 最初は沈木, 次に鲸骨 をへて冷水涌出域へと進出し, 最後に熱水域に到達したと いうことが䢙伝子による解析結果をあとに提出されている (Greene 2002). 他の生物む同様なルートで進出した可能性 が指摘されており，あしそうだとすると固着性二枚貝では 最初のステップすら踏み出していないことになる. 潮間帯 や浅海域ではマガキとムラサキイガイ，あるいはイワガキ Crassostrea nippona とイガイ Mytilus coruscus というよう にそれぞれのニッチが一部重なるように固着性と足系付着 性の二枚貝が対をなすように生息しており，しかも両者と あ個体数が多い，貝類の深海底への進出のプロセスには長 い時間が必要で，その中で起こってきたことについては未 だ不明な点が多いが, 化学合成生物群集の中には固着性の 深海性フジッボ類 (Yamaguchi and Newman 1990; Yamaguchi 1998; Newman 2000; 渡部 2003）が少数知られてお り, 岩盤やチムニーなどの固着基盤す存在する. 力キ型固 着性二枚貝の進出がこれまでなかったことは化学合成生物 群集の特性を考える上で看過できない問題と考えられる. 


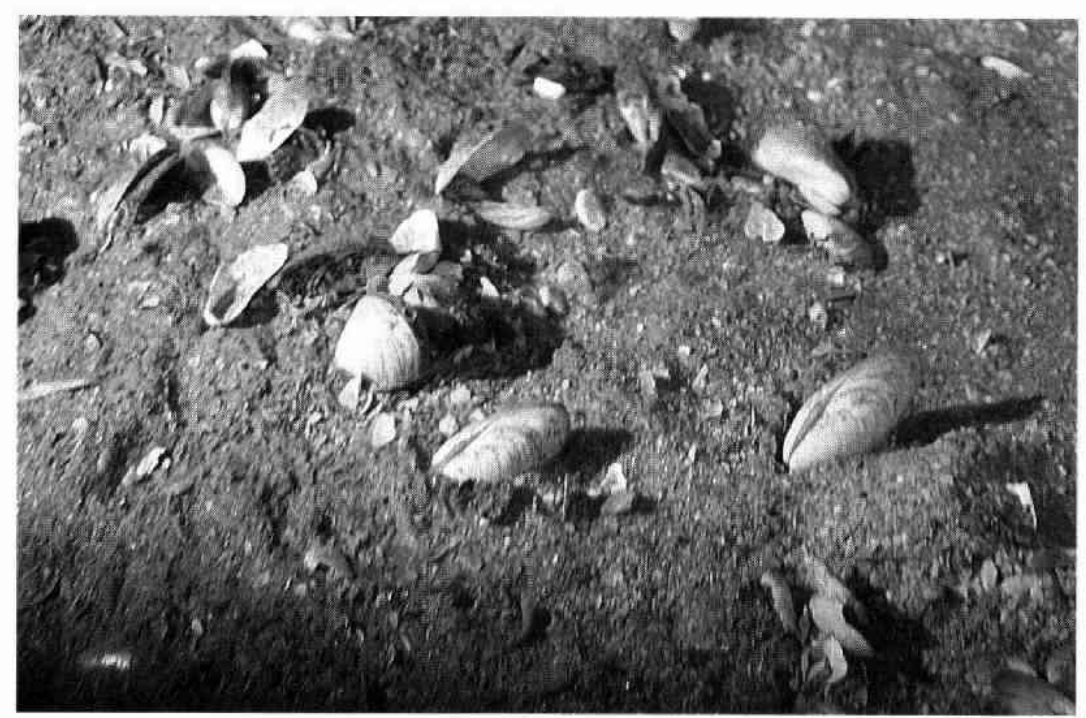

Fig. 1. Deep-sea clam Calyptogena solidissima partly buried in the sediment at a cold seep in the Kuroshima Knolls.

\section{埋在と付着の意味}

シロウリガイ類はガラパゴスシロウリガイ Calyptogena magnifica など一部の種を除けば一般に貝款の前半部を泥 中に埋没させて生活している (Fig. 1)。 また，シンカイヒ バリガイ属は足系を張ることにより海底の岩盤やチム ニ一, 同種他個体, 同種あるいは別種の死款, 殻皮などに 付着して生活している (Fig. 2). 浅海に生息する二枚貝が 泥中に埋在するのは, 捕食者から逃れる, 泥中に定位し一 定方向に足や水管などを向けることにより移動や海底表面 のデトライタスあるいは海底直上のプランクトンなどを取 り入れる (近藤 2001), 干出時に水分を保持する，あるいは 波浪などにより打ち上げられるのを防ぐなどのメリットが 考えられる，しかし，深海に生息するシロウリガイが埋在 するのは泥中加ら硫化水素を得ることが一義的であると考 えられ, 波浪による洗い出しなど浅海域で重要となる環境 要因はその生存にほとんどクリティカルではないと思われ る. 一方, 潮間帯に生息するイガイ科の二枚貝は足系を張 り，同種個体が群集を作りマット状に岩盤表面に付着し 被覆することにより，干出時の温度変化を抑え，水分を 保持し, 波による岩盤からの引き離しを防ぐほか, 新規 加入個体を捕食者加ら保護するなどのメリットを得ている (Paine 1974; Suchanek 1992)。また，ヨーロッパイガイやホ ンヒバリガイ Modiolus modiolus では足系の生産に関与す る要因が調べられており，ヨーロッパイガイでは水の摚乱 頻度や水流の速さが足系生産に大きな影響を与え波や水流 が強い場合は足糸数が多くなることが報告されている (Price 1980, 1982; Young 1985). 砂や泥中に半埋没状態で 生息するホンヒバリカイイでは足系のアンカー機能が報告さ れている (Meadows and Shand 1989). その他, 小型個体で は足糸を切断して移動することや捕食者を含む巻貝を足系
で絡め取り動けなくするなどの報告あある（Day et al. 1991; 岩崎 1999)。このようにイガイ科の浅海種では複数 の足糸の機能が報告されているが，「足糸を張ることによ り動かない」ということが最も重要な要因であると考えら れる.

\section{変化する熱水噴出域の付着基盤}

ところが, チムニーが林立し $200^{\circ} \mathrm{C}$ 以上にもなる熱水が 噴出する熱水噴出域は，1日に数 $10 \mathrm{~cm}$ 以上もチムニーが 成長することや噴出孔の位置が数日で変わるといったこと あしばしば起こるあのと考えられる。したがって, 足糸て 付着するシンカイヒバリガイ属の付着基盤は絶えず変化し ているといってあ過言ではない，足系を張ったチムニーが 崩れたり付着した近傍加ら突然熱水が噴き出してくると いったことは希なことではないと思われる，そのような中 でムムラサキインコガイのように多数の足系をしっかりと 張るという動かないあるいは動けない戦略は, 逆にデメ リットが大きいであろう。むしろ必要に応じて移動しなけ ればならない，祌縄トラフの熱水域に生息するへイトウシ ンカイヒバリガイ Bathymodiolus platifrons は, 研究用に設 置したネットの上に短期間に大型個体が付着していること がある、また，採集した小型のへイトウシンカイヒバリガ イを船上のバットに海水とともに収容すると足を出して移 動し, バットの縁や同種他個体の貝殼に数時間のうちに足 糸を張ること (Fig. 3) が観察されている. これらのこと は, 熱水噴出孔付近ではへイトウシンカイヒバリガイは着 底後足糸を張りずっと 1 か力所にとどまるのではなく, 付着 環境の変化にあわせて必要に応して足系を切断して移動し ていることを示唆している，熱水噴出域では，このような 付着・切断・移動が必要であり，したがって，このような 環境がカキのような固着性二枚貝の熱水噴出域への進出を 


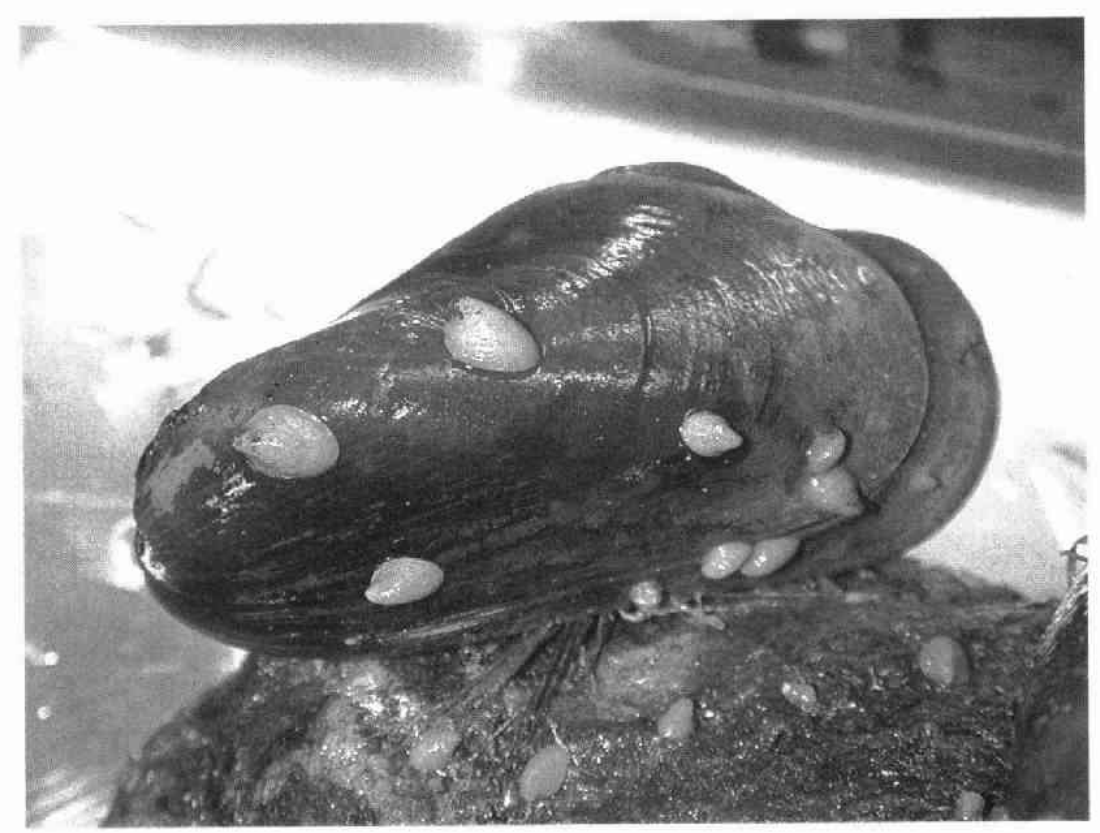

(a)

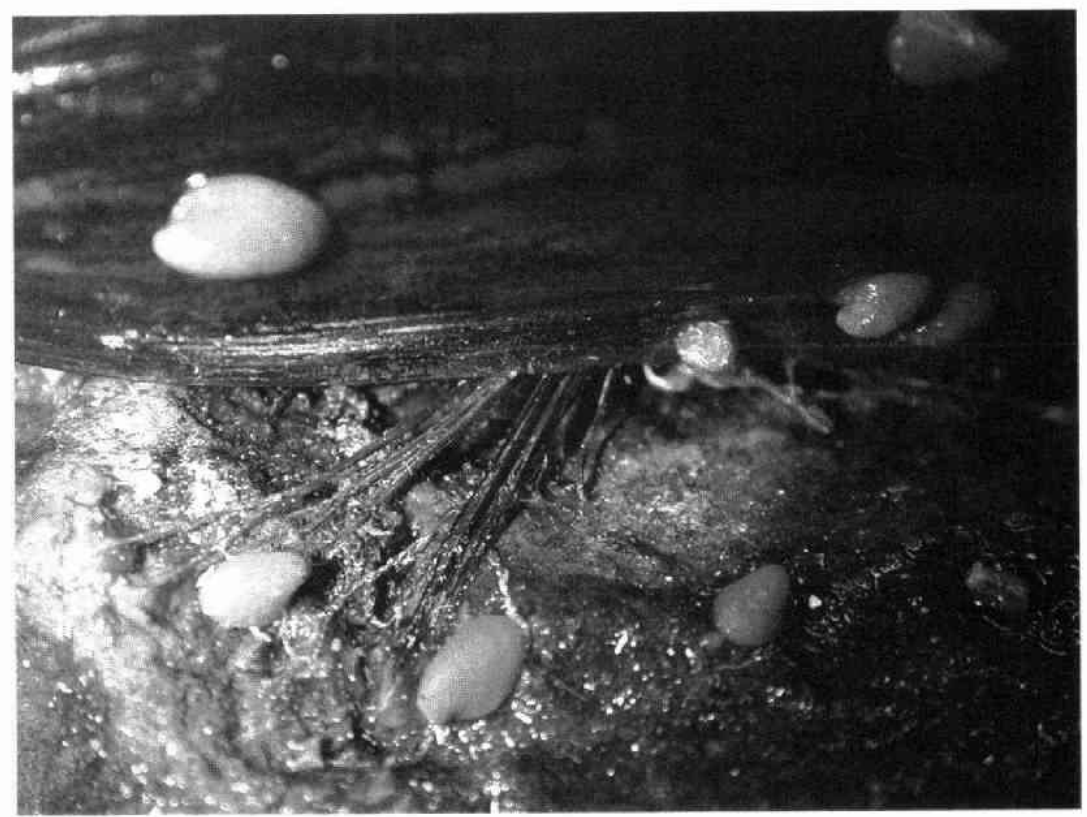

(b)

Fig. 2. (a) Deep-sea mussel Bathymodiolus platifrons attached to the rock surface of a hydrothermal vent of the Hatoma Knoll. Small snails Lepetodrilus sp. are attached to the mussel shell. (b) Byssus at higher magnification.

阻む要因のひとつになっているのかもしれない，

しかし, 冷水湧出域では付着基盤が毎日のように変化す るということはあまり考えられない，したがって比較的安 定した基盤が存在しており固着性生物の進出は可能と考え られるか，実際には生息がみられない。このことから基盤 の安定性だけから固着性生物の深海への進出の有無を論じ るのも早計であると思われる，逆に足系をあつことにより 付着も移動も可能というイガイ科貝類の特性が熱水噴出域 や泠水湧出域, さらには深海そのものへの進出に有利て あったのか, あるいは他の要因が重要なのかという視点か
らの検討が必要であろう.

\section{帯状分布の成因}

泥中への埋在と基盤への付着, それらは浅海でも深海で も足や足糸といった同じ器官により行われる. しかし浅海 と深海では環境が異なる. 足む足系も浅海での機能と深海 での機能は異なる可能性があるということは容易に想像が つく，熱水噴出域ではチムニーの先端から根元までの間に 生物の帯状分布が認められる. 鳩間海丘では噴出口付近に 


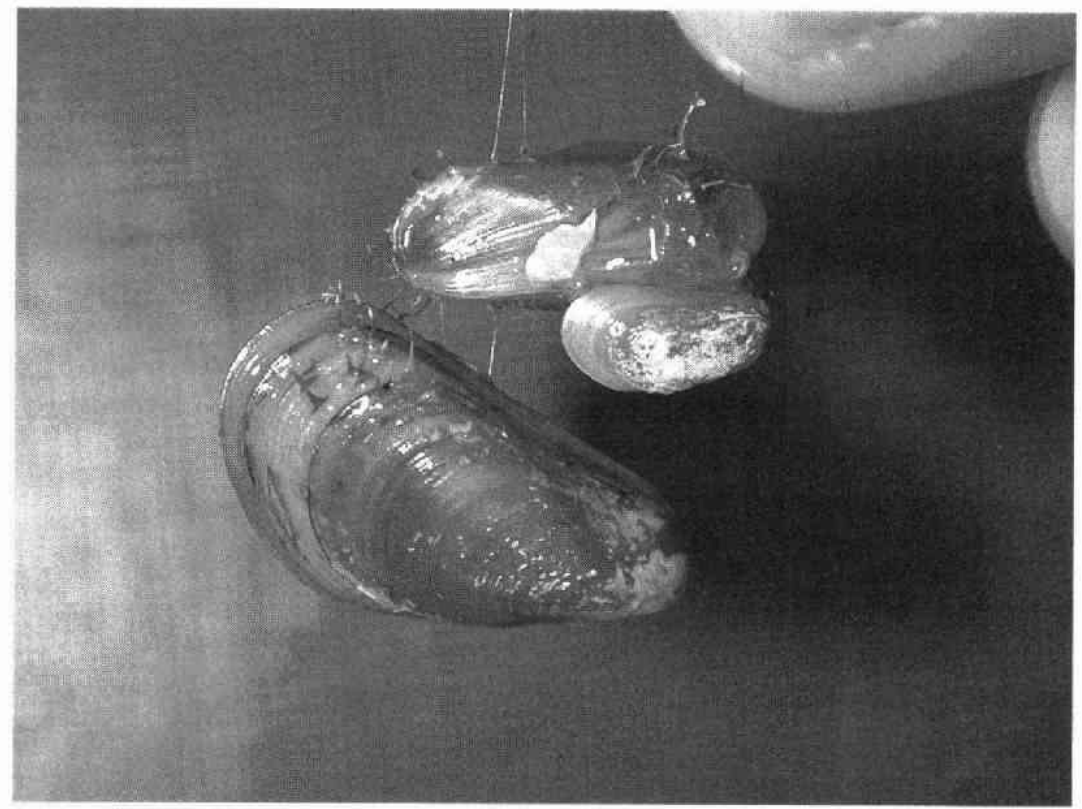

Fig. 3. Byssus formed by deep-sea mussels (Bathymodiolus sp., short-type) artificially cultivated for 24 hrs at $4^{\circ} \mathrm{C}$ (about $2-3$ threads).

はゴエモンコシオリエビ Shinkaia crosnieri が蝟集し，そこ から少し離れてへイトウシンカイヒバリガイが多数付着し ている。ししかし，この帯状分布も潮間帯の帯状分布とは成 因が異なる．潮間帯では海水面の上下による干出と冠水が 生物の分布に大きく関わるが, 深海では熱水や冷水がどこ から出てくるのかといった噴出口の位置やその温度, 組 成,さらにチムニーの成長によって付着基盤が移動したり 増大したり，倒壊によって基盤が消失するという動きのな かで帯状分布が決定されるものと考えられる。また，潮間 帯で重要な上下のレベルではなく噴出口からの距離が生物 の分布に影響するため,「上下」や「帯状」という概念では 括りきれないという点も指摘しておかなければならない。

深海はたしかに特殊な環境である。しかし，へイトウシ ンカイヒバリガイは基本的にはイガイ科二枚貝に特有の貝 殻微細構造と炭酸カルシウムの結晶形をあわせもち (Okoshi et al. unpublished data), 足系を張り付着するという浅 海に生息する近縁種と同様の生活様式を有しており, 一 見, 外部形態や構造, 行動はコンサバティブに見える。し 加し, 上述のように同じ形態, 同じ行動であっても浅海種 上深海種ではその機能は異なった意味をむっている可能性 がある. 分布の成立も潮間帯とは全く異なる要因か関与し ている。これまで化学合成生物群集を構成する生物は「地 球を食べる」という特殊性に関心が集中し, 一見浅海種之 類似の形態や生態についてはその機能の解析が十分に行わ れてこなかったように思う。今後はそ㧈らの解析を進める とともに, 浅海域, 中首域, 深海域といったそれぞれのサ ブシステムの解析だけにとどまらず，それらをつないだ あっとグローバルな解析を積極的に進めていくことが必要 である.

\section{深海のメガベントスの生産量の把握と 今後の展望}

浅海の干潟や岩礁域では, 埋在性や付着性二枚貝の埋在 や付着といった個々の機能を含め, 生物群集の機能解析が 進んでいる. しかし, 深海の化学合成生物群集に㧍いては 無機的環境 (熱水や冷涌水の成分), 生産者 (細菌), 消費 者（ヘンント）という連鎖構造を現存量上生産量を把握し て系統的に解析した研究はこれまでにない，そこで，著者 らは化学合成生態系の機能解析を目的として, メガベント スであるこれら二枚貝の生産に関わる要因についてさまざ まな角度から研究を進めている(藤倉ら 2001, 2003). 干潟 や岩礁域之は異なり, 深海は生物の現存量を把握するとい う生物生産の基礎を押さえることすら難しい. 現存量見積 もりを目的とした深海底にコドラートを設置し (Fig. 4), 写真・ビデオ，そしてスラープガンによる単位面積あたり に生息する個体の全個体採集 (Fig. 4) を組み合わせた新し い解析法を検討するとともに, 学光色素やストロンチウム による貝殼へのマーキング法 (大越 2001; Sato-Okoshi \& Okoshi 2002; Fujikura et al. in press; Okoshi in press）による 成長速度解析などを現在進めている，また，走査型電子顕 微鏡による貝殻微細構造の観察, X 線回折法による貝壳を 構成する炭酸カルシウムの結晶形の解析を炭酸塩補償深度 以深に生息するナラクハナシガイ Maorithyas hadalis (Fujikura et al. 1999) やナラクシロウリガイ Calyptogena fossajaponica, ナギナタシロウリガイ Calyptogena phaseoliformis を含めて楧討を進めている，さらに，埋在性二枚貝につい ては定位の有無とその意味, 足や水管の機能などについて 浅海種と比較しながら検討を進めるとともに付着性二枚貝 


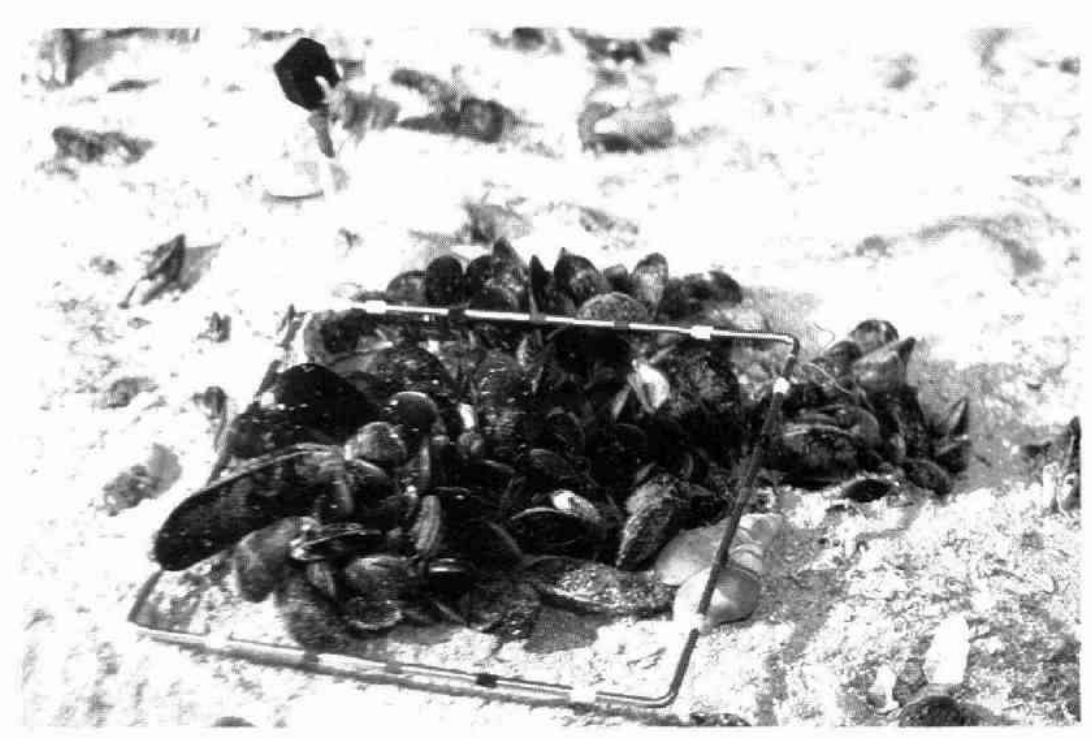

(a)

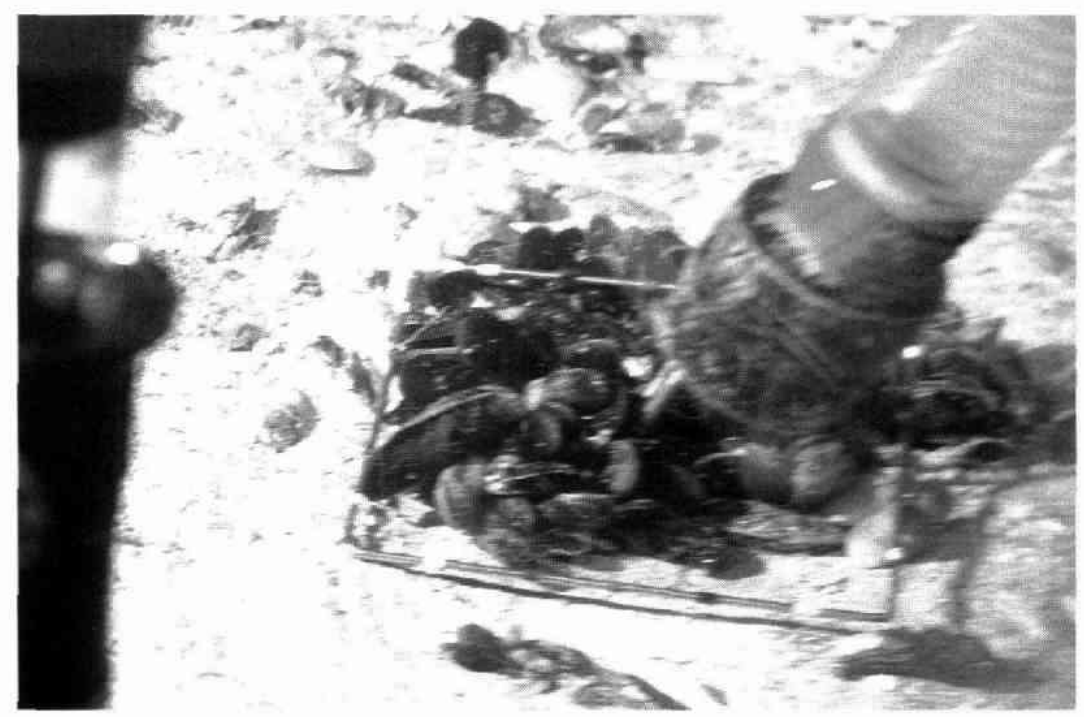

(b)

Fig. 4. (a) Deep-sea mussels (Bathymodiolus sp., long-type) in a $30 \times 30 \mathrm{~cm}^{2}$ quadrant awaiting enumeration. (b) Collecting the sample from the quadrant with a slurp gun.

の行動の解析, 固着や穿孔性二枚貝の探索などを行ってい る.これらの結果を総合して化学合成生態系の構造と機能 を把握するための基礎的知見を得たいと考えている.

謝 辞: 海洋科学技術センター「しんかい2000」運航チームお よび支援四船「なっしま」乗組員の皆様のこ協力と若名のレビュ アーの有益なコメントに感謝いたします。

\section{引用文献}

Day, R. W., A. Barkai and P. A. Wickens 1991. Trapping of three drilling whelks by two species of mussel. Journal of Experimental Marine Biology and Ecology, 149: 109-122.

Fujikura, K., S. Kojima, K. Tamaki, Y. Maki, J. Hunt and T. Okutani 1999. The deepest chemosynthesis-based community yet discovered from the hadal zone, $7326 \mathrm{~m}$ deep, in the Japan Trench.
Marine Ecology Progress Series, 190: 17-26.

滕苗克則・藤原義弘・石橋純一郎・片岡 聡 - 小松徽史・前澤優 子・牧 陽之助・宮崎涼一 三宅裕志 - 岡本和洋 - 土田真二 Lazlo G. Toth • 大越健嗣・山口寿之・山本啓之・山中寿朗・渡

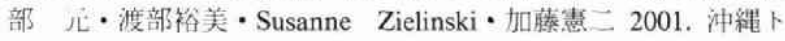
ラフ第阳与那国海丘之徝間海丘における「しんかい2000」シス テムによる熱水生態系調查報告. JAMSTEC Journal of Deep Sea Research, 19: 141-154.

藤倉克則・青木美澄・藤原義弘・一林信亮・今村牧子・石橋純一 郎・岩瀬良一・加藤憲二・小坂紋子・町山栄章・ 三宅裕志・宮

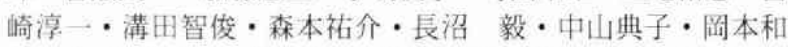
洋 - 大越健嗣 - 大越和加 - 奥谷喬司 - 左藤知子 - Lazlo G. Toth - 土田真二 - 角皆 澗 - 若松弥記 - 渡部裕美 - 山中寿朗 山本啓之 2003.「しんかい2000システム」による南西諸島海域 鳩間海丘・黒島海丘の化学合成生態系調查 (生物・地球化学統 合調查), JAMSTEC Journal of Deep Sea Research, 20: 21-30.

Fujikura, K., K. Okoshi and T. Naganuma. Use of strontium as a 
growth marker for estimation of microscopic growth rate in a bivalve. Marine Ecology Progress Series, in press.

滕原義弘 2003. 化学合成其生システムーベントスと共生細菌の 华接な関係。日本ベントス学会誌，58: 26-33.

Greene, K. 2002. Mussels on the move. Science, 295: 1821-1822.

Harper, E. M. 1991. The role of predation in the evolution of cementation in bivalves. Palaeontology, 34: 455-460.

岩崎敬二 1999. 具のバラタイス, 東海大学出版会, 東京, $294 \mathrm{pp}$.

近藤康生 2001. 二枚貝類の生活梯式とその進化. 池谷仙之・棚部 一成 (編), 古生物の科学 (第 3 巻), 古生物の生活史, 朝倉㫷店, 東京, pp. 149-168.

Meadows, P. S., P. Shand 1989. Experimental analysis of byssus thread production by Mytilus edulis and Modiolus modiolus in sediments. Marine Biology, 101: 219-226.

溝田智俊・山中寿朗 2003. 深海化学合成生物群集加战出現する ベントスのエネルギー獲得戦略：軟体部の炭素，窒素および硫 黄の安定同位体組成による解析, 日本ベント又学会詰，58: 56 69.

Nelson, D. C. and C. R. Fisher 1995. Chemoautotrophic and methanotrophic endosymbiotic bacteria at deep-sea vents and seeps. In, The Microbiology of the Deep-Sea Hydrothermal Vents, Karl, D. M. (ed.), CRC Press, New York, pp. 125-167.

Newman, W. A. 2000. A new genus and species of barnacle (Cirripedia,Verrucmorpha) associated with vents of the Lau Back-Arc Basin: its gross morphology, inferred first juvenile stage and affinities. Zoosystema, 22: 71-84.

大越健嗣 2001. 貝款・具の畨・ゴカイの菊, 成山堂書店, 東京, $164 \mathrm{pp}$.

Okoshi, K. Analyses of hard tissue formation by fluorescent substances in mollusks. Proceedings of the Eighth International Symposium on Biomineralization, in press.

奥谷喬司 2000a. 化学合成軟体動物研究のフロンティア. 総特集 軟体動物学一動问と将来一. 月刊海洋, 号外, pp. 140-145.

奥谷喬司 $2000 \mathrm{~b}$. 日本近海産貝類龱爁, 東海大学出版会, 東京, $1173 \mathrm{pp}$.

Okutani, T., S. Kojima and N. Iwasaki 2002. New and known vesicomyid bivalves recently collected from the western and central Nankai Trough off Shikoku and Honshu, by Deep Sea Research Systems of Japan Marine Science and Technology Center. Venus, 61: $129-140$.

Paine, R. T. 1974. Intertidal community structure, experimental studies on the relationship between a dominant competitor and its principal predator. Oecologia, 15: 93-120.

Price, H. A. 1980. Seasonal variation in the strength of byssal attachment of the common mussel Mytilus edulis L. Journal of the
Marine Biological Association of the United Kingdom, 60: 10351037.

Price, H. A. 1982. An analysis of factors determining seasonal variation in the byssal attachment strength of Mytilus edulis. Journal of the Marine Biological Association of the United Kingdom, 62: 147155.

Sato-Okoshi, W. and K. Okoshi 2002. Application of fluorescent substance to the analysis of growth performance in Antarctic bivalve, Laternula elliptica. Polar Bioscience, 15: 66-74.

Seilacher, A. 1985. Bivalve morphology and function. In, Mollusks, Notes for a Short Course, Broadhead, T. W. (ed.), University of Tennessee, Department of Geological Science, Studies in Geology, 13: $88-101$

Suchanek, T.H. 1992. Extreme biodiversity in the marine environment: mussel bed communities of Mytilus californianus. Northwest Environment Journal, 8: 150-152.

土田英治 2000. 我が国に打ける深海性貝類研究の現状 総特集 軟体動物学:動向之将来- 月刊海洋, 号外, pp. 25-39.

Tunnicliffe, V. 1991. The biology of hydrothermal vents: ecology and evolution. Oceanography and Marine Biology: an Annual Review, 29: 319-407.

Tunnicliffe, V. 1992. The nature and origin of the modern hydrothermal vent fauna. Palaios, 7: 338-350.

Tunnicliffe, V., A. G. McArthur and D. McHugh 1998. A biogeographical perspective of the deep-sea hydrothermal vent fauna. Advances in Marine Biology, 34: 355-422.

渡部裕美 2003. 西太平洋の化学合成生物群集における分散上進 化：熱水噴出域における進化学的研究の対象生物上してのハナ 力コ類. 日本ベントス学会咭，58: 44-49.

Yamaguchi, T. and W. A. Newman 1990. A new and primitive barnacle (Cirripedia: Balanomorpha) from the North Fiji Basin abyssal hydrothermal field, and its evolutionary implications. Pacific Science, 44: 135-155.

Yamaguchi, T. 1998. Review of Chionelasmus darwini (Pilsbry, 1907) (Cirripedia; Balanomorpha): A comparison between the Pacific and Indian Ocean populations. Species Diversity, 3: 117131.

Yamanaka, T., C. Mizota, Y. Maki, K. Fujikura and H. Chiba 2000. Sulfur isotope composition of soft tissues of deep-sea mussels, Bathymodiolus spp., in Japanese waters. Benthos Research, 55: 6368.

Young, G. A. 1985. Byssus-thread production by the mussel Mytilus edulis: effects of environmental factors. Marine Ecology Progress Series, 24: 267-271. 